\title{
Assessment of Healthcare Waste Management Practice in Facilities with Previous Capacity Building on Healthcare Waste Management (HCWM) in Nigeria
}

\author{
Article by, Ugbena, Eneojo Richard \\ Monitoring and Evaluation Management Services - Nigeria (MEMSII) \\ Email: rugbena@yahoo.com
}

\begin{abstract}
Introduction: Health care wastes constitute a small stream of all waste generated by human yet proper disposal of this waste is a great concern because of its hazardous nature. Most developing countries have poor culture of hospital waste management due to competing medical needs and lack of commitment by hospital management. AIDS Support and Technical Assistant Resources (AIDSTAR1) a development partner supported government of Nigeria to build capacity of health care workers in line with World Health Organization (WHO) and national guideline on HCWM.. It is expected that this support would yield the desired result of improving HCWM in Nigeria. This study is to assess the level of implementation of national guideline on HCWM in Nigeria.

Methodology: A cross sectional descriptive study was conducted using key informant interview and direct observation of HCWM practices in 5 facilities selected from 3 out of the 6 priority states supported by AIDSTAR1. The guideline on minimum package for HCWM in Nigeria was used as a tool for assessing level of implementation at each health facility.

Results: There was marked improvement in HCWM practices across the facilities compared to only $2.5 \%$ of facilities who met minimum standard for HCWM as described in the baseline assessment in 2011. All the facilities had infection prevention committee and all the various types of waste boxes were available and used in the facilities for waste segregation. Wastes were evacuated to points of final disposal even though there were some operational challenges with the process. There was high awareness of the hazardous nature of hospital waste and the need to dispose them in a sanitary manner.

Conclusion: Training of all cadres of health care workers including waste handlers, management staffs, and provision of necessary material for HCWM has lead to improved HCWM in Nigeria. It is hereby recommended that government should ensure that guideline for minimum package of healthcare waste management are continuously implemented in health facilities in line with the national policy on HCWM.
\end{abstract}

Key words: Healthcare waste management, Hazardous health waste, National healthcare waste management guideline, Healthcare waste segregation.

\section{Introduction}

Healthcare waste (HCW) is a by-product of healthcare that includes sharps, non-sharps, blood, body parts, chemicals, pharmaceuticals, medical devices and radioactive materials. Even though HCW form a small stream of total waste generated daily, it draws a lot of attention because it contains potentially hazardous substances. According to WHO, hazardous waste make up $20 \%$ of hospital waste [1]. Of these $20 \%$, infectious and anatomical waste account for $15 \%$, sharps represent $1 \%$, chemical and pharmaceutical $3 \%$ and genotoxic waste, radioactive matters and heavy metal account for the remaining $1 \%$. Poor management of HCW exposes healthcare workers, waste handlers, patients, visitors to the hospital and nearby community to infections, toxic effects and injuries [2]. HCWM is first of all a management issue before being a technical one and therefore completely depend on the commitment of both administrative and political authorities as well as the entire staff within health facilities [3]. In most developing countries because of several competing health need for meager 
resources, hospital management may not see waste management as apriority. For the management and the facility staffs to dedicate their resources and time for hospital wastes management will depend on how much information they have about the hazardous nature of hospital waste and the need to dispose them in a sanitary manner.

In Nigeria, waste management is a general concern to the extent that some states declare sanitation days as a monthly exercise to emphasize the need for people to clean their environment and commit them at least once in a month to embark on the cleaning of their environment. In the hospital environment where persons are formally employed for the purpose of cleaning the environment, how well this is done depend on how the worker perceive the importance of their task. An important requirement for proper HCWM is the development and implementation of a HCWM plan which requires going through a number of steps and having in mind the different levels of health facilities where it will be implemented. Guided by WHO guideline on HCWM, a 5 years Nigerian national healthcare waste management plan was developed by the national HCWM technical working group [4] This plan together with national policy on healthcare waste management and guidelines were formally approved by the Federal Executive Council in 2012. The Federal Government had in the past made some efforts in the form of provision of high temperature incinerators at tertiary health facilities, which form part of the healthcare policy and strategic plan. The guideline document which should guide the health facilities consist of 10 steps for improving HCWM in Nigeria. The steps includes: 1) raising awareness of the problem especially amongst policy makers; 2) develop a Policy on HCWM that define the rational for HCWM and what should be achieved; 3) setting up a strategy which is basically stating what steps must be taken to achieve the objectives that have been listed in the policy; 4) conduct an assessment of the current situation using for example the WHO rapid assessment tool;. 5) draft a HCWM Plan that should contain a national action plan using for example the WHO general guidance document; 6) consolidate the legal \& regulatory frameworks; 7) standardize HCWM practices in line with the national guidelines; 8) strengthen the institutional capacities both human and financial resources; training, etc.; 9) set up waste management plans at all relevant levels and 10) establish a monitoring plan.

Aware of the numerous challenges with HCWM in Nigeria and in line with WHO recommendation [5] on the core principles for achieving safe and sustainable management of health-care waste that donors and partners should include a provision in their health program assistance to cover the costs of sound health-care waste-management systems; and that to achieve acceptable practices in health-care waste management, all managers and other personnel must receive appropriate training. In 2011, AIDSTAR-1 a United State Agency for International Development (USAID) funded project, supported a baseline assessment in five priority states to determine the status of HCWM practices in Nigeria [6].The assessment found that few facilities have policy document to guide health care workers in safe medical injection and waste management services. In $72.1 \%$ of the facilities, sharp containers were not available in every corner where injection took place. $86.2 \%$ of waste handlers had not been trained in safe handling of medical waste. One third (33.8\%) had no protective equipment. Sharps in open containers were found in $31 \%$ of the facilities. Majority of the facility used unsafe disposal methods. Only two facilities met the requirement for a minimum package for health care waste management consisting of proper waste segregation; storage in a locked area; treatment using medium or a high temperature incineration, dumping in a protected pit, or transportation for offsite treatment; disposal in an ash pit if onsite high temperature incineration was used. The study recommended that government should provide national guideline and other policy document on health care waste management to all facilities, train all cadres of health care workers on injection safety and HCWM, provide personal protective equipment and institute procedures for sharp waste management. Other previous study in Nigerian has also shown poor awareness of hospital waste hazard and its management among workers [7] the study recommended training of health workers staffs to create awareness on wastes, the hazards and existing guidelines and various forms of treatment for waste. Another 
study [8] showed that even when knowledge of healthcare waste management was high, the practice was not adequate.

The findings from the baseline assessment lead to setting up the national technical working group who developed the national guideline on HCWM. Also AIDSSTAR-1, a USAID funded implementing partner through (President Emergency Plan for AIDS Relief (PEPFAR, embark on series of training for health facilities across the country as well as providing policy documents and seed stocks of waste collection bins in line with the national guideline. The following was the steps taken to implement HCWM at the various facilities by the organization; 1) advocacy to the selected facilities 2) conduct baseline assessment to know the status of HCWM in the facility; 3) train health care workers, waste handlers and store keepers on HCWM; 4) provide policies and guidelines on hospital waste management; 5) provide materials for waste management e.g. covered pedal bin/liners, wheel bins, aprons, gloves and boots, safety boxes for sharps. The facilities were also provided with list of vendors from where they can get the materials if they ran out of stock. To determine whether the facilities were meeting the minimum HCWM standards, there was a routine supportive supervision to the health facilities after the training using the supportive supervision check list. The facility must respond yes to all the observations variables on the minimum package for HCWM for it to be counted as meeting minimum standards for HCWM; The minimum standard/package for HCWM are: 1) Formation of a viable, functional sustainable Infection Prevention Committee (IPC) that meet regularly, 2) Availability of HCWM Plan (Integrated or standalone) 3) Waste Segregation at source, 4) Waste handling during transportation with the use of Personal Protective Equipment (PPE), 5) Internal transport from point of generation to storage point using wheel bins, 6) A secured storage point, 7) Standard treatment of waste, 8) Final disposal in the manner that is safe. Depending on the level of facilities, the minimum requirement differs in the area of formation of infection control committees and type of final disposal system. While a tertiary hospital and secondary health facilities must have a functional infection control committee at the primary health facilities, a focal person for infection control is sufficient. Also in the area of final disposal, tertiary hospital and secondary hospital are expected to have incinerator and an ash pit or sanitary landfill offsite. Both secondary and primary health facility at the minimum should have a designated burial pit that is well protected from both animal and man. This study is set to assess the impact of the capacity building by AIDSTAR-1. It was believed that the training would improve the practice of HCWM practices across facilities to be able to meet the minimum standard for national guideline on HCWM.

\subsection{Objectives}

Overall objective was to assess the level of implementation of national health care waste management guideline among the facilities that received capacity building on HCWM services by AIDSTAR-1

\subsection{Specific objectives}

1. To determine the level of compliance of the facilities with national guideline on HCWM set out by the national technical working group

2. To determine if the facilities meet the standard for health care waste management

3. To determine unsafe practices that could predispose to nosocomial infection, environment pollution and community infection.

\section{Methodology}

The study was carried out in 3 states out of the 6 priority states where AIDSTAR1 provided capacity building to health facilities on health care management. 
South American Journal of Public Health

Volume 4, Issue 2, 2016

\subsection{Study design}

A cross sectional descriptive study was conducted with key informant interview and facility walk- through to observe practice of health care waste management in the facilities

\subsection{Sampling technique}

The package for HCWM differs from level of facilities therefore, in selecting the facilities to be visited, it was mandatory that all levels of facilities supported are represented namely: tertiary, secondary and primary health facilities. Through a multistage sampling, 3 states were randomly selected from the 6 priority states supported by AIDSTAR-1. In the 3 states, a total of 9 facilities were supported by AIDSTAR1 for HCWM services out of which 5 were randomly selected.

\subsection{Data collection method}

Data was collected through key informant interview and direct observation during a facility walk through. In all the facilities visited, a designated head of infection control committee or the secretary were interviewed on what steps have been taken to implement minimum package for HCWM in the facility using the government guideline. After the interview, a facility walk through was conducted through some of the departments or units in the facilities associated with high activities that could generate waste. The departments and units include; emergency area, wards, theatres, laboratories, ANC \& and child welfare clinics. During the walk through it was observed if waste are segregated at source, presence of safety boxes for sharps, minimum of Black and Yellow or Red Covered Pedal Bin/Liner, use of rubber gloves, boots \& face mask for waste handlers, and for incinerator operator, if there were respirator, boots \& heat resistant gloves; designated routes for Wheelie Bins, Secured space or location not accessible to unauthorized personnel for storing filled safety boxes prior to treatment or transportation, autoclaving high temperature incineration with emission control, high temp incineration medium temp incineration burn and bury in a protected pit, bury in a protected pit without burning, off site treatment, ash pit/landfill (if final disposal is on-site and using a high temperature incinerator) and burial in a protected pit.

\subsection{Ethical consideration}

Prior to the field visit, the state ministry of health was contacted on the planned assessment that gave approval and agreed to be part of the visit. The hospital managements were informed who equally gave their approval. The infection control committee in each of the facilities equally gave their approval and agreed that the chairman and/or the secretary of the committee should grant interview.

\subsection{Study limitations}

1. Only very few facilities were covered during the study

2. Interview was only conducted among the chairman or secretary of IPC

\section{Results}

The study was conducted over 2 weeks with visit to the 3 selected states. In each facility, either the chairman or the secretary or both of infection control committee were interviewed followed by facility walk through to observe practices related to HCWM. Below are the findings:

Table 1 Characteristics of facilities visited by level of health services

\begin{tabular}{|l|l|l|}
\hline Level of facility & Frequency & $\mathbf{( \% )}$ \\
\hline Tertiary & 1 & 20 \\
\hline Secondary & 2 & 40 \\
\hline Primary & 2 & 40 \\
\hline Total & 5 & 100 \\
\hline
\end{tabular}


Five facilities were visited out of which $40 \%$ were secondary, another $40 \%$ were primary and $20 \%$ tertiary health facilities

Table 2 Types of waste generated by level of health facilities

\begin{tabular}{|l|l|l|l|l|}
\hline \multirow{2}{*}{ Level of facility } & \multicolumn{3}{|l|}{ Types of waste } \\
\cline { 2 - 5 } & $\begin{array}{l}\text { General } \\
\text { waste }\end{array}$ & $\begin{array}{l}\text { Hazardous } \\
\text { waste }\end{array}$ & $\begin{array}{l}\text { Dangerous } \\
\text { waste }\end{array}$ & $\begin{array}{l}\text { Chemical } \\
\text { waste }\end{array}$ \\
\hline Tertiary & 1 & 1 & 1 & 1 \\
\hline Secondary & 2 & 2 & 2 & 2 \\
\hline Primary & 2 & 1 & 1 & 1 \\
\hline Total & 5 & 4 & 4 & 4 \\
\hline
\end{tabular}

All the 5 facilities visited were generating general and hazardous waste except a primary health facility that generate only general waste

Table 3 Existence of infection prevention committee by level of facilities

\begin{tabular}{|l|l|l|}
\hline \multirow{2}{*}{ Level of facility } & \multicolumn{2}{|l|}{ Existence of IPC } \\
\cline { 2 - 3 } & Yes & NO \\
\hline Tertiary & 1 & - \\
\hline Secondary & 2 & - \\
\hline Primary & 1 & 1 \\
\hline Total & 4 & 1 \\
\hline
\end{tabular}

All the facilities visited had infection prevention committee except a primary health facility that did not have any committee but represented by a focal person on infection control

Table 4 Availability of annual HCWM plan

\begin{tabular}{|l|l|l|}
\hline \multirow{2}{*}{ Level of facility } & \multicolumn{2}{|c|}{ Existence of HCWM plan } \\
\cline { 2 - 3 } & Yes & No \\
\hline Tertiary & - & 1 \\
\hline Secondary & - & 2 \\
\hline Primary & - & 2 \\
\hline Total & 0 & 5 \\
\hline
\end{tabular}

The table shows that none of the facilities visited had an annual health HCWM plan

Table 5 Uses of waste bin by level of facility

\begin{tabular}{|l|l|l|l|l|l|}
\hline \multirow{2}{*}{$\begin{array}{l}\text { Level of } \\
\text { facility }\end{array}$} & \multicolumn{5}{|l|}{ Type of waste bins } \\
\cline { 2 - 7 } & $\begin{array}{l}\text { Safety } \\
\text { boxes \%) }\end{array}$ & Black (\%) & Yellow (\%) & Red (\%) & Brown (\%) \\
\hline Tertiary & 1 & 1 & 1 & 1 & - \\
\hline Secondary & 2 & 2 & 2 & 2 & 1 \\
\hline Primary & 2 & 2 & 1 & 1 & - \\
\hline Total & $5(100 \%)$ & $5(100 \%)$ & $4(80 \%)$ & $4(80 \%)$ & $1(20 \%)$ \\
\hline
\end{tabular}

The table shows that all the facilities visited had different types of waste bins for waste segregation. All the facilities had safety and black bin but one primary health facility did not have yellow nor red bin while only one secondary facility (20\%) had all the boxes including brown box. 
South American Journal of Public Health

Volume 4, Issue 2, 2016

Table 6 Use of personal protective equipments by waste handlers

\begin{tabular}{|l|l|l|}
\hline \multirow{2}{*}{ Level of facility } & \multicolumn{2}{|l|}{ Use of personal protective equipments } \\
\cline { 2 - 3 } & Yes (\%) & No (\%) \\
\hline Tertiary & 1 & - \\
\hline Secondary & 2 & - \\
\hline Primary & 2 & - \\
\hline Total & $5(100 \%)$ & $0(0 \%)$ \\
\hline
\end{tabular}

In all the facility visited, PPEs are available and used during evacuation of waste from service point to storage point and during the process of transportation for final disposal

Table 7 Mode of transportation of waste within the facility

\begin{tabular}{|l|l|l|}
\hline \multirow{2}{*}{ Level of facility } & \multicolumn{2}{|c|}{ Mode of transportation } \\
\cline { 2 - 3 } & Use wheel bin (\%) & Bin move by waste handlers \\
\hline Tertiary & 1 & - \\
\hline Secondary & 2 & - \\
\hline Primary & - & 2 \\
\hline Total & $4(60 \%)$ & $2(40 \%)$ \\
\hline
\end{tabular}

In the teaching hospital and secondary facilities, wheel bins were used for transport of waste from point of service to a temporary storage location

Table 8 Availability of a designated room for storage of waste before disposal

\begin{tabular}{|l|l|l|}
\hline \multirow{2}{*}{ Level of facility } & \multicolumn{2}{|l|}{ Type of storage facility } \\
\cline { 2 - 3 } & $\begin{array}{l}\text { Waste stored in } \\
\text { designated room (\%) }\end{array}$ & $\begin{array}{l}\text { No designated storage } \\
\text { room (\%) }\end{array}$ \\
\hline Tertiary & 1 & - \\
\hline Secondary & 1 & 1 \\
\hline Primary & 2 & - \\
\hline Total & $4(80)$ & $1(20)$ \\
\hline
\end{tabular}

Eighty percent of the facility visited had a designated room where wastes are temporary stored before final disposal. Only in one secondary facility (20\%), wastes are move from point of service to final disposal

Table 9 Location of treatment of waste by level of facility

\begin{tabular}{|l|l|l|l|}
\hline \multirow{2}{*}{ Level of facility } & \multicolumn{3}{|l|}{ Type of treatment } \\
\cline { 2 - 4 } & $\begin{array}{l}\text { Onsite incinerator } \\
\text { and burning of } \\
\text { general waste (\%) }\end{array}$ & $\begin{array}{l}\text { Offsite incinerator } \\
\text { and burning of } \\
\text { general waste (\%) }\end{array}$ & $\begin{array}{l}\text { Sanitary } \\
\text { land fill (\%) }\end{array}$ \\
\hline Tertiary & 1 & - & - \\
\hline Secondary & - & 1 & 1 \\
\hline Primary & 1 & 1 & - \\
\hline Total & $2(40)$ & $2(40)$ & $1(20)$ \\
\hline
\end{tabular}

Only two (40\%) of the facilities visited had functional incinerator within the premises, another two (40\%) had offsite incinerator while one $(20 \%)$ of the secondary facilities practiced sanitary land filling. 
South American Journal of Public Health Volume 4, Issue 2, 2016

Table 10 Summary finding of minimum package of HCWM by level of facilities visited

\begin{tabular}{|c|c|c|c|c|c|}
\hline \multirow{2}{*}{$\begin{array}{l}\text { Guideline on } \\
\text { minimum } \\
\text { package of } \\
\text { HCWM }\end{array}$} & \multicolumn{2}{|l|}{ Lagos State } & \multicolumn{2}{|l|}{ Bauchi State } & \multirow{2}{*}{$\begin{array}{l}\text { Cross River State } \\
\text { General hospital }\end{array}$} \\
\hline & General hospital & $\begin{array}{l}\text { Primary health } \\
\text { care }\end{array}$ & Teaching hospital & Primary health care & \\
\hline $\begin{array}{l}\text { Type of waste } \\
\text { generated }\end{array}$ & $\begin{array}{l}\text { General, hazardous and } \\
\text { chemical wastes }\end{array}$ & General waste & $\begin{array}{l}\text { General, hazardous and } \\
\text { chemical wastes }\end{array}$ & $\begin{array}{l}\text { General and hazardous } \\
\text { waste }\end{array}$ & $\begin{array}{l}\text { General, hazardous and } \\
\text { chemical wastes }\end{array}$ \\
\hline $\begin{array}{l}\text { Formation of } \\
\text { IPC }\end{array}$ & $\begin{array}{l}\text { The hospital has a } 7 \text { man } \\
\text { infection prevention } \\
\text { committee which meets } \\
\text { once in a month to } \\
\text { discuss on issue of } \\
\text { infection prevention. }\end{array}$ & Nil & $\begin{array}{l}\text { Infection control committee } \\
\text { in place Committee holds } \\
\text { meeting monthly. } \\
\text { Membership cut across all } \\
\text { hospital departments... }\end{array}$ & $\begin{array}{l}\text { Infection control } \\
\text { committee in place } \\
\text { which include facility } \\
\text { staff as well as } \\
\text { community members }\end{array}$ & $\begin{array}{l}\text { Infection control committee } \\
\text { in place Committee holds } \\
\text { meeting monthly. } \\
\text { Membership cut across all } \\
\text { hospital department } \\
\text { including hospital } \\
\text { management and state } \\
\text { ministry of health } \\
\text { representatives }\end{array}$ \\
\hline $\begin{array}{l}\text { Availability of } \\
\text { HCWM Plan }\end{array}$ & $\begin{array}{l}\text { No annual plan on } \\
\text { HCWM }\end{array}$ & $\begin{array}{l}\text { No annual plan on } \\
\text { HCWM }\end{array}$ & No annual plan on HCWM & $\begin{array}{l}\text { No annual plan on } \\
\text { HCWM }\end{array}$ & No annual plan on HCWM \\
\hline $\begin{array}{l}\text { Waste } \\
\text { Segregation }\end{array}$ & $\begin{array}{l}\text { Different waste bins as } \\
\text { follows: } \\
\text { Safety Boxes - sharp } \\
\text { objectives } \\
\text { Black bin liner - general } \\
\text { waste } \\
\text { Yellow Bin Liner- } \\
\text { infectious waste } \\
\text { Red bin liner- highly } \\
\text { infectious waste } \\
\text { Brown Bin Liner- } \\
\text { chemical waste }\end{array}$ & $\begin{array}{l}\text { Different waste } \\
\text { bins as follows: } \\
\text { Safety Boxes - } \\
\text { sharp objectives } \\
\text { Black bin liner - } \\
\text { general waste }\end{array}$ & $\begin{array}{l}\text { Different waste bins as } \\
\text { follows: } \\
\text { Safety Boxes - sharp } \\
\text { objectives } \\
\text { Black bin liner - general } \\
\text { waste } \\
\text { Yellow Bin Liner: } \\
\text { infectious waste } \\
\text { Red bin liner: highly } \\
\text { infectious waste }\end{array}$ & $\begin{array}{l}\text { Different waste bins as } \\
\text { follows: } \\
\text { Safety Boxes - sharp } \\
\text { objectives } \\
\text { Black bin liner - } \\
\text { general waste } \\
\text { Yellow Bin Liner: } \\
\text { infectious waste } \\
\text { Red bin liner: highly } \\
\text { infectious waste }\end{array}$ & $\begin{array}{l}\text { Different waste bins as } \\
\text { follows: } \\
\text { Safety Boxes - sharp } \\
\text { objectives } \\
\text { Black bin liner - general } \\
\text { waste } \\
\text { Yellow Bin Liner: } \\
\text { dangerous waste } \\
\text { Red bin liner: hazardous } \\
\text { waste }\end{array}$ \\
\hline
\end{tabular}


South American Journal of Public Health

Volume 4, Issue 2, 2016

\begin{tabular}{|c|c|c|c|c|c|}
\hline $\begin{array}{l}\text { Handling Use } \\
\text { of PPE }\end{array}$ & $\begin{array}{l}\text { Waste handlers in the } \\
\text { hospital have heavy duty } \\
\text { gloves, face mask, apron } \\
\text { and booths used during } \\
\text { handling of wastes }\end{array}$ & $\begin{array}{l}\text { Waste handlers in } \\
\text { the hospital have } \\
\text { heavy duty gloves, } \\
\text { and booths that are } \\
\text { used when } \\
\text { handling wastes }\end{array}$ & $\begin{array}{l}\text { Waste handlers in the } \\
\text { hospital have heavy duty } \\
\text { gloves, face mask, apron } \\
\text { and booths that are used } \\
\text { when handling wastes }\end{array}$ & $\begin{array}{l}\text { Waste handlers in the } \\
\text { hospital have heavy } \\
\text { duty gloves, face mask, } \\
\text { apron and booths that } \\
\text { are used when handling } \\
\text { wastes }\end{array}$ & $\begin{array}{l}\text { Waste handlers in the } \\
\text { hospital have heavy duty } \\
\text { gloves, face mask, apron } \\
\text { and booths that are use } \\
\text { when handling wastes }\end{array}$ \\
\hline $\begin{array}{l}\text { Internal } \\
\text { transport }\end{array}$ & $\begin{array}{l}\text { Waste is wheeled using } \\
\text { wheel bin to storage } \\
\text { point before final } \\
\text { disposal }\end{array}$ & $\begin{array}{l}\text { Waste packed in } \\
\text { ordinary bin } \\
\text { before burning }\end{array}$ & $\begin{array}{l}\text { Waste is wheeled using } \\
\text { wheel bin before final } \\
\text { disposal }\end{array}$ & $\begin{array}{l}\text { Waste are packed in } \\
\text { wheeled bin before } \\
\text { final disposal }\end{array}$ & $\begin{array}{l}\text { Waste is wheeled using } \\
\text { wheel bin before final } \\
\text { disposal }\end{array}$ \\
\hline Storage & $\begin{array}{l}\text { A room constructed with } \\
\text { lock and key which is } \\
\text { not accessible to } \\
\text { unauthorized personnel. } \\
\text { Safety boxes are kept } \\
\text { prior to transportation } \\
\text { for final disposal. }\end{array}$ & $\begin{array}{l}\text { Filled safety boxes } \\
\text { kept in the store } \\
\text { prior to } \\
\text { transportation for } \\
\text { final disposal. }\end{array}$ & $\begin{array}{l}\text { One room in the psychiatric } \\
\text { ward was designated to } \\
\text { keep shapes before } \\
\text { incineration }\end{array}$ & $\begin{array}{l}\text { One room in the PHC } \\
\text { was use to keep shapes } \\
\text { before incineration }\end{array}$ & $\begin{array}{l}\text { Waste are temporarily } \\
\text { stored in the wheel bin } \\
\text { before final disposal }\end{array}$ \\
\hline Treatment & Off site treatment & Off site treatment & $\begin{array}{l}\text { Have incinerator within } \\
\text { where sharps are burnt }\end{array}$ & $\begin{array}{l}\text { Have incinerator where } \\
\text { sharps are burnt. }\end{array}$ & Off site treatment \\
\hline Disposal & $\begin{array}{l}\text { The hospital has a dump } \\
\text { site where wastes are } \\
\text { kept before } \\
\text { transportation to the } \\
\text { final dump site for } \\
\text { incineration. The dump } \\
\text { site in the hospital has } \\
\text { no door or lock to keep } \\
\text { unauthorized people } \\
\text { from throwing things } \\
\text { into it. }\end{array}$ & $\begin{array}{l}\text { Lagos Waste } \\
\text { Management } \\
\text { Authority } \\
\text { (LAWMA pick } \\
\text { waste from the } \\
\text { PHC but most } \\
\text { times this does not } \\
\text { happen In such } \\
\text { condition, sharps } \\
\text { waste are sent to } \\
\text { another facility for }\end{array}$ & $\begin{array}{l}\text { Has incinerator where all } \\
\text { sharps are burnt. Also have } \\
\text { a dump site where other } \\
\text { wastes are dumped before it } \\
\text { is burnt or packed by State } \\
\text { Environmental Agency. The } \\
\text { Agency packed the waste } \\
\text { fortnightly. } \\
\text { Also cosmopolitan waste } \\
\text { management organization is } \\
\text { contracted to clean the }\end{array}$ & $\begin{array}{l}\text { Have an Ash Pit for } \\
\text { putting all the ashes } \\
\text { from the incinerator. }\end{array}$ & $\begin{array}{l}\text { Sanitary land filling method } \\
\text { is practice... }\end{array}$ \\
\hline
\end{tabular}


South American Journal of Public Health Volume 4, Issue 2, 2016

\begin{tabular}{|l|l|l|l|l|}
\hline & & $\begin{array}{l}\text { incineration. The } \\
\text { back of the PHC is } \\
\text { used to burn } \\
\text { general waste. }\end{array}$ & hospital. & \\
\hline
\end{tabular}


South American Journal of Public Health

Volume 4, Issue 2, 2016

\section{Discussion}

The level of implementation of national guidelines on healthcare waste management as prescribed by the national technical working group was described is this study. The study found some level of improvement over the findings from the baseline assessment in 2011 by AIDSTAR-1 even though there are variations in-terms of compliance with all the steps. Compliance to the guideline largely depends on the willingness and commitment of both the facility management as well as the staffs to implement the HCWM intervention strategy. Various cadres of the hospital staffs ranging from management through clinical staffs and the waste handlers were trained. Seed stocks of necessary materials like the various bin liners, and in some cases support to the facility to own and run an incinerator. All the facilities generate both general and hazardous waste which must be disposed in a sanitary manner in line with international practices since no waste is completely human friendly. Some of the facilities practiced onsite incineration and burning of general refuses. Use of medium or high temperature incineration is a common technique for treating waste, as it can reduce waste mass by $70 \%$ and volume by up to $90 \%$, as well as providing recovery of energy from waste to generate electricity [9]. However, Incineration does not solve the problem of waste as the final product is converted into an ash that contains some of the most toxic concentrations of substances, such as dioxins, and heavy metals. The generation and safe disposal of this toxic waste is very problematic as pollutants from landfill sites have been known to seep out, polluting local water sources, and once they contaminate the water table, their removal is considered to be almost impossible. The EU Commission has stated that final waste from incineration may be one of the most important sources of dioxins in the future. [10] Also the emission from incineration contain large amount of particulate matters that have been associated with cardiovascular and respiratory morbidity and mortality while the heavy metals in the emission have been associated with carcinogen. Burning of refuse within the hospital constitute hazard to both the patients and people living in the environment. Plastics made from chlorine or fluorine is halogenated plastics that give off dioxin when burnt. Dioxin is a known human carcinogen and the most potent synthetic carcinogen ever tested in laboratory animals. Dioxin is about 10,000 more potent carcinogens than the next highest chemical carcinogen di-ethanol amine [10]. The effect of these substances may be slow but its long term effect is very devastating. In Nigeria Ogbonna et al in 2012 [11] documented that huge quantities of general wastes in hospitals are plastics, a pointer to hazard experience when these waste are burnt within the hospital environment. It is also documented that improperly disposed hazardous health care waste like syringes and needles in the absence of sterilization can cause infections of Hepatitis B, C and HIV. Abah and Ohimain, 2011[12] documented that chemical waste poses indirect risks to humans through direct environmental effects by contaminating soil and ground-water. This also collaborate the study by Ogbonna et al 2007 [11] who stated that environmental contamination by waste is worsen by the fact that when untreated wastes are beaten by rain they may be washed into the drainages, rivers, streams and other waters thus endangering human and aquatic lives.

Various bin liners were available in all the facilities visited except for brown bin liner that was only found in one of the facilities. The availability of the bin liners enables waste segregation at point of services. Non-separation of hospital wastes endangers scavengers and waste handlers in addition to the exposure of wild animals such as birds, flies and rodents that facilitate the spreading of germs from infectious medical wastes to nearby environments. The practice of waste segregation as observed in this study is an improvement over previous findings in Lagos by Olubukola [13] who described that HCW management practices in two general hospitals in Lagos was marred by poor waste segregation practices as well as lack of instructive posters on waste segregation and disposal of general wastes. Segregation of wastes according to Ndidi et al.(2009) [7] and Abah and Ohimain (2011) [12] would result in a clean solid waste stream which could be easily, safely and cost effectively managed through recycling, composting and land filling. However, the absence of brown bin liners from most of the facilities means that more need to be done to ensure all necessary bins are available at 
point of services. Brown bin liners are use for collection of pharmacy waste. Its absence means that pharmacy wastes are mixed with other waste and may be disposed inappropriately.

Despite the support given to the facilities, none of the facilities had HCWM plan. Lack of HCWM plan is an indication of poor management commitment. HCWM plan is required to analyze the effort made by the facility to implement the minimum package of HCWM guideline. Such analysis will identify gap in implementation and will guide management plan towards achieving full implementation. Related to this was lack of national plan of action and strategic plan at the facilities. These strategic documents are to guide facility specific plan of action. The documents were approved by the federal executive council in 2013 and it is expected that by 2015 these document should be available at health facilities. The situation here is similar to the finding during the baseline study where about $80.6 \%$ of the facilities did not have any national policy or guidelines.

A good observation that was made during the study was the existence of IPC in all the facilities visited. Depending on the level of facility, an infection prevention committee is recommended for a larger hospital while a focal person may be designated in a primary health facility. In the baseline survey, only about $22.3 \%$ of all the facilities had infection control committee. The existence of a committee whose sole function is to ensure that hospital waste are manage in such a manner to remove or reduce hazards associate with healthcare waste management is commendable. The committee meets regularly to review issues around waste management in the facility and make recommendation to management. In one of the primary health facility, community members were involved in the committee. The involvement of community member in the IPC emphasizes the need for people living around the facilities to be aware of the dangers of hospital waste.

The study also revealed that waste handlers are provided with the necessary equipment for self protection from contamination with hazardous hospital waste. The base line assessment showed that about $34 \%$ of waste handlers did not have PPE. In this study, PPE are provided by the health facilities and this was also observed during the facility walk through. Both the waste handlers in the facilities and those responsible for final disposal were provided PPE. Handling of hazardous waste without appropriate PPE predisposes waste handlers to risk of nosocomial infection such as HBV, HBV and HIV.

Wheel bins are recommended for transport of waste from point of service to store where they are temporarily stored before final disposal. The use of wheel bin is a hygienic method of waste transportation. In one of the facility visited, waste bin is still being carried by handlers to the point where they are stored. This practice may result to contact with hazardous agent. Effort should be made by the management to provide wheel bins in such facility. Also none existence of a temporary location for storage of waste (as observed in one of the facilities) before final disposal may mean that waste will remain at point of collection for longer time before they are removed

Despite the sites meeting the minimum standards, there are some operational issues that must be addressed in order to harness the full benefit of hospital waste management. Some of the bins used in the wards have no liner in them because the available bins were bigger than the bins. The lack of bin liner will make evacuation of waste from the bins difficult and may predispose handlers to contamination. In this same facility, the way to the incinerator was bushy and water logged which makes it difficult for waste handlers to carry out the incineration as at when due. In another facility, one of the urban trucks was stocked in the mud during an operation thus there was no subsequent collection of refuse from that facility. Yet in another facility, the dump site in the hospital had no door or lock to keep unauthorized people from throwing things into it. This will allow scavengers access to the dump site with the attendance risk. The pit for dumping and burning of wastes in one facility was filled up with waste littering around. Because the pit was already filled up, subsequent wastes were dumped indiscriminately around the pit. These unsafe practices are associated with various forms of hazards. Waste management and treatment options should first protect the healthcare workers and the patients and minimize impacts on the environment [11] 
South American Journal of Public Health

Volume 4, Issue 2, 2016

\section{Conclusions}

The current Healthcare waste management is an improvement over the situation that existed as at 2011. However a lot need to be done especially from the management point of view in order to reap the full benefit of healthcare waste management. The wide spread application of this study is limited owning to the small sample size and the narrow scope of the study. A larger sample size that cut across more states and interview that also includes facility staff and waste handlers may give a better insight into the implementation of minimum package of HCWM in Nigeria.

\section{Recommendations}

1. Healthcare waste management plan did not exist in any of the facility. This is an indication of the level of commitment by the hospital management. For a successful healthcare waste management, each facility should develop a plan base on the national policy and guideline for HCWM and commit resources that enable smooth running of HCWM.

2. Some operational and logistic challenges were identified during the study. This again point to level of commitment by the hospital management. It is not enough to identify a location for storage and disposal of waste but these must be maintained. When refuse pit is filled up or there are no available trucks to evacuate waste to final disposal site, the waste will continue to pose hazard in the hospital.

3. Burning of refuse within the hospital or use of incinerator without emission control poses a lot of risk to patients, visitors and the people living in the hospital environment. All facilities must identify an offsite location for burning of general waste and all incinerators must have emission control. Alternative to incineration are now available such as use of autoclaves, microwaves and stream treatment integrated with internal mixing and chemical treatment. These newer method of disinfection are safer.

4. Routine monitoring of implementation of minimum package for HCWM is highly recommended by the members of the infection prevention committee. Also from time to time state ministry of health or even the federal ministry of health in collaboration with environmental protection agencies should conduct external supervisory visit to facilities.

\section{Acknowledgement}

My greatest thanks to God almighty for his guidance and re-direction of the course of my knowledge I wish to acknowledge the immense support I got from Dr. Chidima Anyanwu whose encouragement enable me to decide for this course. My special gratitude to Dr. Kalo Obasi whose lecture stimulated my interest to carry out this study on environmental health

\section{References}

[1] Abah, S. O. Ohimain, E. J. Healthcare waste management in Nigeria: A case study. Journal of Public Health and Epidemiology Vol 3(3). Pp. 99-110 March 2011.

[2] Assessment of injection safety in selected local government areas in five states in Nigeria. 2011 baseline study.

[3] Azuike, E. C. Adimma, E. D. Nwabueze, S. A. Azuike, E. B. Mbanazuru, V. A. Epundu, U. U. Enwonwa, K. G. Chikizie, N. I. Ajafor, C. C. Onebunne, E. M. and Obi, D. C. Healthcare waste management: what do health workers in Nigeria tertiary hospital know and practices. Science Journal of Public Health. 2015, 3(1): pp 114-118. Publish online February 2, 2015. Available at http://www.,science publishing group.com

[4] Charles, H. L. Alvin, W. M. John, P. B. and Gordon, M. Uses of incineration municipal solid waste ash. Available at www.pdci.com/journal/sustainability, July2, 2010

[5] Irish Doctors Environmental Association. Incineration and the health effect. June 15, 2006. Available at www.ideairland.org/library/incinerator-and-their-health-effect 


\section{South American Journal of Public Health \\ Volume 4, Issue 2, 2016}

[6] National guideline for Health Waste Management; Prepared by Healthcare waste management technical working group. Available at www.wds.worldbank.org/.../E16340NHCWMP10sophie0version0170A

[7] Ngwuluka, N. Ochekpe, N. Odumosu P., and John, S. Waste Management in Health Establishment within Jos Metropolis, Nigeria. African Journal of Environmental Science and Technology. Vol 3(12), pp 459-465, December 2009. Available at http://www.academic Journals.org/ASEST

[8] Ogbonna, D. N. Chidah, A. and Ubani, N. Waste management options for health care waste in Nigeria: A case study of Port-Harcourt hospitals. Journal of Public Health and epidemiology. Vol. 4(6). Pp 156-169. June 2012. Available at http://www.academicjournals.org/JPHE

[9] Olubukola, B. O. (2009). Comparative analysis of health waste management practice in two general hospital in nigeria. Available at http://www.eco-web.com/edi/inedx.htm. Assessed on October 25th, 2015.

[10] WHO fact sheet No. 253 (2011); Waste from Healthcare Activities. Available at WHI.int/mediacentre/factsheets. Assessed on October 28, 2015

[11] WHO guidance for healthcare waste management in LICs. Available at www.healthcarewaste.org/home. Assessed on October 28, 2015

[12] WHO, United Nations Environment program/SBC; National Health-Care Waste Management Plan. Guidance Manual. Available at www.WHO.int/ater_sanitation_health/medicalwaste/en/guidance manual. Assessed on October 28, 2015.

[13] WHO 2007; Core principles for achieving safe and sustainable management of health-care waste "Safe management of waste from health care activities, $2^{\text {nd }}$ edition, www.healthcarewaste.org/fileadmin 